\title{
Comparison of growth and survival of single strains of Lactococcus lactis and Lactococcus cremoris during Cheddar cheese manufacture
}

\author{
Rhitika Poudel, ${ }^{1 *}$ Randall K. Thunell, ${ }^{1,2} \odot$ Craig J. Oberg, ${ }^{1,3} \oplus$ Sophie Overbeck, ${ }^{1}$ Michael Lefevre, ${ }^{1}$ \\ Taylor S. Oberg, ${ }^{1} \odot$ and Donald. J. McMahon ${ }^{1} \dagger[1$ \\ ${ }^{1}$ Department of Nutrition, Dietetics and Food Sciences, Utah State University, Logan 84322 \\ ${ }^{2}$ Vivolac Cultures Corporation, Greenfield, IN 46140 \\ ${ }^{3}$ Department of Microbiology, Weber State University, Ogden, UT 84408
}

\begin{abstract}
Traditionally, starter cultures for Cheddar cheese are combinations of Lactococcus lactis and Lactococcus cremoris. Our goal was to compare growth and survival of individual strains during cheesemaking, and after salting and pressing. Cultures used were 2 strains of L. lactis (SSM 7605, SSM 7436) and 2 strains of $L$. cremoris (SSM 7136, SSM 7661). A standardized Cheddar cheese make procedure was used that included a $38^{\circ} \mathrm{C}$ cook temperature and salting levels of 2.0,2.4, $2.8,3.2$, and $3.6 \%$ from which were selected cheeses with salt-in-moisture levels of 3.5, 4.5, and 5.5\%. Vats of cheese were made using each strain on its own as biological duplicates on different days. Starter culture numbers were enumerated by plate counting during cheesemaking and after $6 \mathrm{~d}$ storage at $6^{\circ} \mathrm{C}$. Flow cytometry with fluorescent staining by SYBR Green and propidium iodide was used to determine the number of live and dead cells in cheese at the different salt levels. Differences in cheese make times were strain dependent rather than species dependent. Even with correction for average culture chain length, cheeses made using L. lactis strains contained $\sim 4$ times $(\sim 0.6 \log )$ more bacterial cells than those made using L. cremoris strains. Growth of the strains used in this study was not influenced by the amount of salt added to the curd. The higher $\mathrm{pH}$ of cheeses with higher salting levels was attributed to those cheeses having a lower moisture content. Based on flow cytometry, $\sim 5 \%$ of the total starter culture cells in the cheese were dead after $6 \mathrm{~d}$ of storage. Another 3 to $19 \%$ of the cells were designated as being live, but semipermeable, with $L$. cremoris strains having the higher number of semipermeable cells.
\end{abstract}

Key words: microbiology, starter culture, semipermeable, salt

Received July 2, 2021

Accepted November 22, 2021.

*Current address: Glanbia Nutritionals, Twin Falls, Idaho.

†Corresponding author: Donald.McMahon@usu.edu

\section{INTRODUCTION}

Traditionally, Cheddar cheese is made using a starter culture consisting of a mixture of both Lactococcus lactis and Lactococcus cremoris strains. Over the years these bacteria have had various designations and were initially known in the cheese industry as Streptococcus lactis and Streptococcus cremoris until they were reclassified as subspecies of L. lactis (Crow et al., 1993). Recently, L. lactis ssp. cremoris was elevated back to the species level as L. cremoris ( $\mathrm{Li}$ et al., 2019). Acid production by L. lactis strains is generally faster, but $L$. cremoris strains are considered more suitable for flavor development. Some of this preference has been associated with $L$. lactis strains growing to higher numbers during cheesemaking and being associated with bitter flavor development during aging of the cheese (Lowrie et al., 1972). Strains of L. lactis associated with poor flavor development are typically less sensitive to the cook temperatures reached during Cheddar cheese manufacture and undergo 3 to 5 generations of growth during cheese manufacture (Martley and Lawrence, 1972). In contrast, nonbitter strains only had about one generation of growth before a cook temperature of $38^{\circ} \mathrm{C}$ was reached. It is interesting that if the cook temperature is lowered, so supposedly nonbitter strains continue to grow throughout cheesemaking and reach high numbers, the subsequent cheese also developed bitterness (Lowrie and Lawrence, 1972).

When a multiple-strain starter culture is used, it is expected that the least temperature-sensitive strains will dominate by the end of Cheddar cheese manufacture by one log or more, so that the bacterial population will eventually consist of 90 to $99 \%$ L. lactis strains (Limsowtin et al., 1977). This would be even more likely when a slightly higher cook temperature (e.g., $39^{\circ} \mathrm{C}$ ) is used (Lee and Collins, 1976). More heat-sensitive strains decline in number by about $50 \%$, whereas less heat-sensitive strains continue to replicate during the later phases of cheesemaking (Martley and Lawrence, 1972). 
Previous research has shown that when L. cremoris is grown in a liquid medium at elevated temperatures, some strains will stop replication even though they continue to actively ferment lactose with the production of lactic acid (Turner and Thomas, 1975; Chen et al., 2015). This uncoupling of growth rate and acid production is strain dependent (Breheny et al., 1975) and occurs as cells strive to maintain cellular homeostasis under environmental stresses, in this case elevated temperature (Hillier et al., 1975).

In Cheddar cheese manufacturing, a slowing down of acid production is observed as curd is heated above the optimum temperature for growth of lactococcal starter cultures. Whether cell replication continues is unclear. After draining the whey, the curd cools during cheddaring, and acid production rate increases, so cell replication can potentially re-commence (Lee and Collins, 1976). At typical cook temperatures used in Cheddar cheese manufacture, L. lactis strains are less likely to undergo uncoupling, whereas L. cremoris strains are considered less adaptive to stresses such as heating and will uncouple acid production from cell metabolism and replication (Kim et al., 1999).

Advances in starter culture production (direct-to-vat cultures, phage-inhibitory buffered bulk starter media, and external and internal $\mathrm{pH}$-control bulk starter systems) have reduced variation in culture acid production rates previously experienced by cheesemakers (Richardson et al., 1977). Many challenges related to starter culture selection have been assumed by companies providing cultures to the cheese industry. However, understanding the performance of starter cultures with respect to the effect of cooking temperature on their growth, acid production rate, as well as survival during cheesemaking and after salting are still important.

Some lactococcal strains are sensitive to salt such that their numbers can drop by 2 logs or more to $<1 \%$ of their original number after salting and overnight pressing (Limsowtin et al., 1977). In a mixed-strain culture, a drop of 0.5 to $1 \mathrm{log}$ in lactococcal numbers is not unusual even at typical salt levels [i.e., $\sim 4.7 \%$ saltin-moisture (S/M) content (McMahon et al., 2014)]. Starter culture population in the cheese will then be dominated by the more salt-tolerant strains. At lower salt concentrations, there is usually no immediate drop in lactococcal numbers after salting.

The aim of this study was to compare the growth and acid production of L. lactis strains to L. cremoris strains throughout cheese manufacture and their survival upon salting. Each vat of Cheddar cheese was made using just one strain, selected from lactococcal strains used in commercial starter cultures, with cheese salted at 3 different salt levels representing low, standard, and high levels of S/M (i.e., 3.5\%, 4.5\%, and 5.5\%).

\section{MATERIALS AND METHODS}

\section{Starter Cultures}

Lactococcus lactis SSM 7605, L. lactis SSM 7436, L. cremoris SSM 7136, and L. cremoris SSM 7661 were obtained from Vivolac Cultures Corporation. Cultures were grown at $31^{\circ} \mathrm{C}$ using external $\mathrm{pH}$-control in a dairy-based lactose-limited production medium. The $\mathrm{pH}$ was controlled between 5.8 and 6.0 with the addition of ammonium hydroxide. Incubation was continued until substrate exhaustion occurred (when no further decrease in $\mathrm{pH}$ was detected) and then cooled to $4^{\circ} \mathrm{C}$. Culture activity was measured by adding 0.3 $\mathrm{mL}$ of culture to $10 \mathrm{~mL}$ of UHT processed milk (Gossner Foods) in a test tube (in duplicate) and incubated in a water bath at $32^{\circ} \mathrm{C}$ for $2.5 \mathrm{~h}$. Culture activity was the difference in mean $\mathrm{pH}$ of the inoculated milk compared with $\mathrm{pH}$ of uninoculated control tubes of milk. Subsequently, culture addition to milk in the cheese vat was set at $0.45 \%$ (wt/wt) when starter activity was 1.5 . If culture activity was lower, then the amount added to the vat was increased to $0.50 \%$. Conversely, if the activity was higher, such as 1.6 or 1.7 , the percentage used for cheesemaking was reduced to $0.4 \%$ or $0.35 \%$, respectively.

Cheese Manufacture. Fresh cow milk was obtained from the George B. Caine Dairy Research and Teaching Center (Wellsville, UT) and transported to the Gary Haight Richardson Dairy Products Laboratory at Utah State University (Logan). Milk was pasteurized $\left(72^{\circ} \mathrm{C}\right.$ for $15 \mathrm{~s}$ ) and $544 \mathrm{~kg}$ of pasteurized milk was pumped into a Tetra Scherping horizontal cheese vat (Tetra Pak Cheese and Powder Systems Inc.).

Milk was warmed to $31^{\circ} \mathrm{C}$, then starter culture was added according to its activity. After mixing for $5 \mathrm{~min}$, $45 \mathrm{~mL}$ of double-strength chymosin ( 650 international milk clotting units/mL; Maxiren; DSM Food Specialties USA Inc.) was added and the milk allowed to set undisturbed. Thirty minutes after renneting, the curd was cut. After cutting and healing (10 min), the curdwhey mixture was stirred for $10 \mathrm{~min}$, heated to $38^{\circ} \mathrm{C}$ over $25 \mathrm{~min}$, and then stirred for another $20 \mathrm{~min}$. The curd-whey mixture was pumped from the vat onto a drain table (Kusel Equipment Co.) and mechanically stirred until a curd $\mathrm{pH}$ of 6.3 was reached $(\sim 25 \mathrm{~min})$. The remaining whey was then drained, and the dry curd stirred for $\sim 2 \mathrm{~min}$. The curd was allowed to mat, cut into slabs, and cheddared for a target time of 180 min and target curd $\mathrm{pH}$ of 5.45 .

Curd was milled, separated into five $11-\mathrm{kg}$ portions, and placed into open plastic containers. Curd was mixed with either $2.0,2.4,2.8,3.2$, or $3.6 \%$ (wt/wt) salt using 3 applications with 5 min between each ap- 
plication. Salted curd was allowed to stand for $5 \mathrm{~min}$ before being placed into plastic cheesecloth-lined stainless steel hoops and pressed in a horizontal press for 3 $\mathrm{h}\left(140 \mathrm{kPa}, \sim 20^{\circ} \mathrm{C}\right)$. The cheese was then de-hooped, cut into $\sim 1$-kg pieces, individually vacuum packaged, and stored at $6^{\circ} \mathrm{C}$.

Sampling. During cheesemaking, a milk sample was collected after culture addition, and curd samples after cutting, before draining, at curd pack, and before salting. The $\mathrm{pH}$ was measured using a glass combination $\mathrm{pH}$ electrode. Milk and curd samples were immediately prepared for plate counting as described below. Cheese was sampled after $6 \mathrm{~d}$ of storage at $6^{\circ} \mathrm{C}$ with bacterial numbers enumerated using both plate counting and flow cytometry, and for proximate analysis.

Proximate Analysis. Cheese was shredded and moisture content measured by weight loss after $18 \mathrm{~h}$ in a vacuum oven at $80^{\circ} \mathrm{C}$ using triplicate subsamples. Salt was measured by mixing $5.00 \mathrm{~g}$ of shredded cheese with $98.20 \mathrm{~g}$ of distilled water in a stomacher bag (Seward Ltd.) for $4 \mathrm{~min}$ at $260 \mathrm{rpm}$. The slurry was filtered to remove cheese particles and the filtrate analyzed using a chloride analyzer (model 926, Corning Diagnostic Corp.) using triplicate subsamples. The S/M concentration was calculated as salt/(moisture + salt) and expressed as a percentage. The $\mathrm{pH}$ was measured by stomaching $20 \mathrm{~g}$ of grated cheese with $10 \mathrm{~g}$ of distilled water for $1 \mathrm{~min}$ at $260 \mathrm{rpm}$, then measured using a glass electrode.

Microbial Analysis. Eleven grams of milk, curd, or cheese was stomached with $99 \mathrm{~mL}$ of sterile $2 \%$ (wt/ wt) sodium citrate buffer for $4 \mathrm{~min}$ at $260 \mathrm{rpm}$. One milliliter aliquots were then serially diluted with $9 \mathrm{~mL}$ of $1 \%$ sterile peptone dilution blanks. One hundred microliters of sample of each dilution was plated on both M17 and Reddy's agar, and aerobically incubated at $32^{\circ} \mathrm{C}$ for $24 \mathrm{~h}$. The L. cremoris strains were counted within a 30- to 40-h window whereas L. lactis strains were counted within 36 to $48 \mathrm{~h}$ (Reddy et al., 1972). Total bacterial cell numbers were calculated by multiplying colony-forming units by average chain length.

\section{Chain Length}

On a separate occasion, a loopful of milk-grown culture was spread on a microscope slide, air-dried then heat fixed by passing the slide through a flame 3 times. The slide was allowed to cool and the culture was Gram stained. Slides were examined at $1,000 \times$ using a $100 \times$ oil immersion objective lens. The number of cells in each bacterial chain in a field were counted. A minimum of 5 fields were examined. An average chain length was then determined.

\section{Flow Cytometry}

Cheese was sampled after $6 \mathrm{~d}$ of storage. Eleven grams from within each block was stomached in 99 $\mathrm{mL}$ of sterile $2 \%$ (wt/wt) sodium citrate solution for $4 \mathrm{~min}$ at $260 \mathrm{rpm}$. A $1,000-\mu \mathrm{L}$ aliquot of slurry was then diluted 10-fold with $0.2-\mu \mathrm{m}$ (Corning Inc.) filtered buffered peptone (Thermo Fisher Scientific) and centrifuged at 7,800 $\times g(10,000 \mathrm{rpm})$ for $15 \mathrm{~min}$ (Microfuge Lite; Beckman Coulter Life Sciences). The supernatant was discarded, and the pellet was re-suspended in 1,000 $\mu \mathrm{L}$ of $0.2-\mu \mathrm{m}$ filtered saline (Gibco; Thermo Fisher Scientific) and then further diluted 10-fold with filtered saline.

To 1,000 $\mu \mathrm{L}$ of diluted sample of milk or cheese was added $1 \mu \mathrm{L}$ of propidium iodide (PI; Sigma-Aldrich) and $5 \mu \mathrm{L}$ of SYBR Green I nucleic acid gel stain (SG; Invitrogen; 10,000 $\times$ concentrate in dimethylsulfoxide, Thermo Fisher Scientific) and incubated for $15 \mathrm{~min}$ at $37^{\circ} \mathrm{C}$. Measurements were obtained using a BD Accuri C6 plus flow cytometer (Becton Dickinson and Company). Excitation wavelength was $488 \mathrm{~nm}$ and fluorescent emission collected through a $530 / 30 \mathrm{~nm}$ band pass filter for SG-induced fluorescence (FL1) and PI fluorescence collected through a >670 nm band pass filter (FL3). All parameters were collected as logarithmic signals using a threshold of 2,000 on FL1. A dilution factor of $10^{3}$ was determined as optimum for a bacterial population in cheese of about $10^{8}$ to $10^{9}$ cells $/ \mathrm{g}$.

Positions of live and dead cells on the cytographs were determined by inoculating a mixed-strain lactococcal starter culture (DVS 850, Chr. Hansen Laboratories) into UHT sterilized milk (Gossner Foods), which was incubated overnight at $37^{\circ} \mathrm{C}$. A portion of the milk was examined as is, whereas a separate portion containing only dead cells was obtained by heating the cultured milk at $85^{\circ} \mathrm{C}$ for 12 min. Each milk sample was then diluted 500-fold in PBS buffer and prepared for flow cytometry and analyzed as described above.

\section{Statistical Analysis}

The experiment was performed in duplicate with vats of cheese manufactured on separate days using a single strain of starter culture prepared on separate occasions. For each vat, after the curd was milled it was divided into 5 portions that were then individually salted at different levels and each pressed into a 9-kg block of cheese. After testing the salt and moisture contents of the cheese, 3 blocks were selected for the study that best fit the target S/M levels of 3.5, 4.5, and 5.5\%. Statistical analysis was performed using MS Excel 365 version 2011 (Microsoft Corp.) and Statistical Analysis System version 15.1 (SAS Institute Inc.) analysis tools. 
Tukey's honestly significant difference at a $5 \%$ level of significance was used to compare bacterial cell numbers.

\section{RESULTS AND DISCUSSION}

\section{Cheese Manufacturing}

During cheese manufacture, there were some slight differences in manufacturing times between replicate vats because of differences in maintaining target temperatures, but this did not affect the overall trends. As seen in Table 1, in each species classification, one of the strains resulted in a shorter make time than the other. Both L. lactis SSM 7605 and L. cremoris SSM 7661 had average make times of $4 \mathrm{~h}$, whereas L. lactis SSM 7436 and L. cremoris SSM 7136 required make times of $6 \mathrm{~h}$ or longer. Starter cultures were added based upon their activity measured at $32^{\circ} \mathrm{C}$ and differences in acidification rates between strains became apparent as curd was warmed from the set temperature $\left(31^{\circ} \mathrm{C}\right)$ to the cook temperature $\left(38^{\circ} \mathrm{F}\right)$. For the faster strains, the curd was ready to be drained ( $\mathrm{pH} 6.3$ ) at $2 \mathrm{~h}$ after starter addition, whereas the slower strains required about $3 \mathrm{~h}$.

Acidification profiles during cheesemaking are shown in Figure 1 based upon the fastest replicate for each strain. Because of slower acidification during cheddaring and time constraints to complete cheese manufacture, the curd produced using L. lactis SSM 7436 and L. cremoris SSM 7136 was milled at $\mathrm{pH} \sim 5.6$ rather than the target $\mathrm{pH}$ of 5.45 . The extended time to reach the required $\mathrm{pH}$ during cheesemaking for L. lactis SSM 7436 and L. cremoris SSM 7136 demonstrates that without prior knowledge of a culture's heat sensitivity, it would be necessary to determine the activity of the culture over the temperature range encountered during cheesemaking (Lowrie et al., 1972), rather than just using isothermal incubation at the set temperature.

Even though, L. lactis and L. cremoris are considered as being fast and slow, respectively (Fernández et al., 2011), the acidification rate during cheesemaking depended more on the individual strain rather than its species classification. Both L. lactis SSM 7605 and L. cremoris SSM 7661 maintained a fast rate of acid production even after heating the curd to $38^{\circ} \mathrm{C}$. In contrast, acid production by L. lactis SSM 7436 and L. cremoris SSM 7136 slowed down at $38^{\circ} \mathrm{C}$ so it took 1.8 and 2.4 times longer, respectively, from when $38^{\circ} \mathrm{C}$ was attained until the curd $\mathrm{pH}$ reached 6.3 and was ready to be drained. For L cremoris SSM 7136, the acid production rate did not increase until the curd had cooled during cheddaring.

\section{Microbial Numbers During Cheese Manufacture}

Although the milk was sampled after culture addition and before renneting, there had apparently been insufficient mixing of the starter into the milk in the enclosed vat within the 5 min of stirring. Plate count numbers were lower than expected and varied between replicates and were up to 3 logs lower than what was measured 40 min later after cutting. From our experience, lactococcal starter cultures have generation times of about $60 \mathrm{~min}$ at $31^{\circ} \mathrm{C}$ (data not shown) so there could not be sufficient cell replication to reach the numbers measured in the curd. The measurement of number of bacteria in the milk was considered invalid because of insufficient mixing. Stirring continued for another 10 min after adding the rennet with more consistent numbers obtained when the curd was sampled after cutting. Even for a high activity culture, the 45 min of time between starter culture addition and curd sampling after cutting would only allow for less than one generation of replication even for a very active external $\mathrm{pH}$-controlled bulk starter culture.

When using Reddy's agar for enumerating lactococci, L. lactis strains typically form large white colonies, whereas L. cremoris strains usually form smaller yellow colonies (Figure 2). This morphology difference is based on the ability of L. lactis to hydrolyze arginine to create ammonia, whereas L. cremoris does not, although atypical strains are found in each species. All strains used in this study gave white or yellow colonies as expected based upon their species designation when plated as pure cultures. However, when curd made using L. cremoris SSM 7136 was sampled after whey drainage, both white and yellow colonies were observed even though it was counted within the 40-h window required to avoid loss of yellow color in Reddy's agar. We

Table 1. Average Cheddar cheese make times from the starter culture addition to draining and milling of curd using single strains of external pH-control Lactococcus starter culture

\begin{tabular}{llcc}
\hline Species & Strain & $\begin{array}{c}\text { Time until draining } \\
\text { whey (min) }\end{array}$ & $\begin{array}{c}\text { Time until milling } \\
\text { curd (min) }\end{array}$ \\
\hline Lactococcus lactis & SSM 7605 & 125 & 232 \\
L. lactis & SSM 7436 & 163 & 363 \\
Lactococcus cremoris & SSM 7136 & 192 & 379 \\
L. cremoris & SSM 7661 & 124 & 243 \\
\hline
\end{tabular}




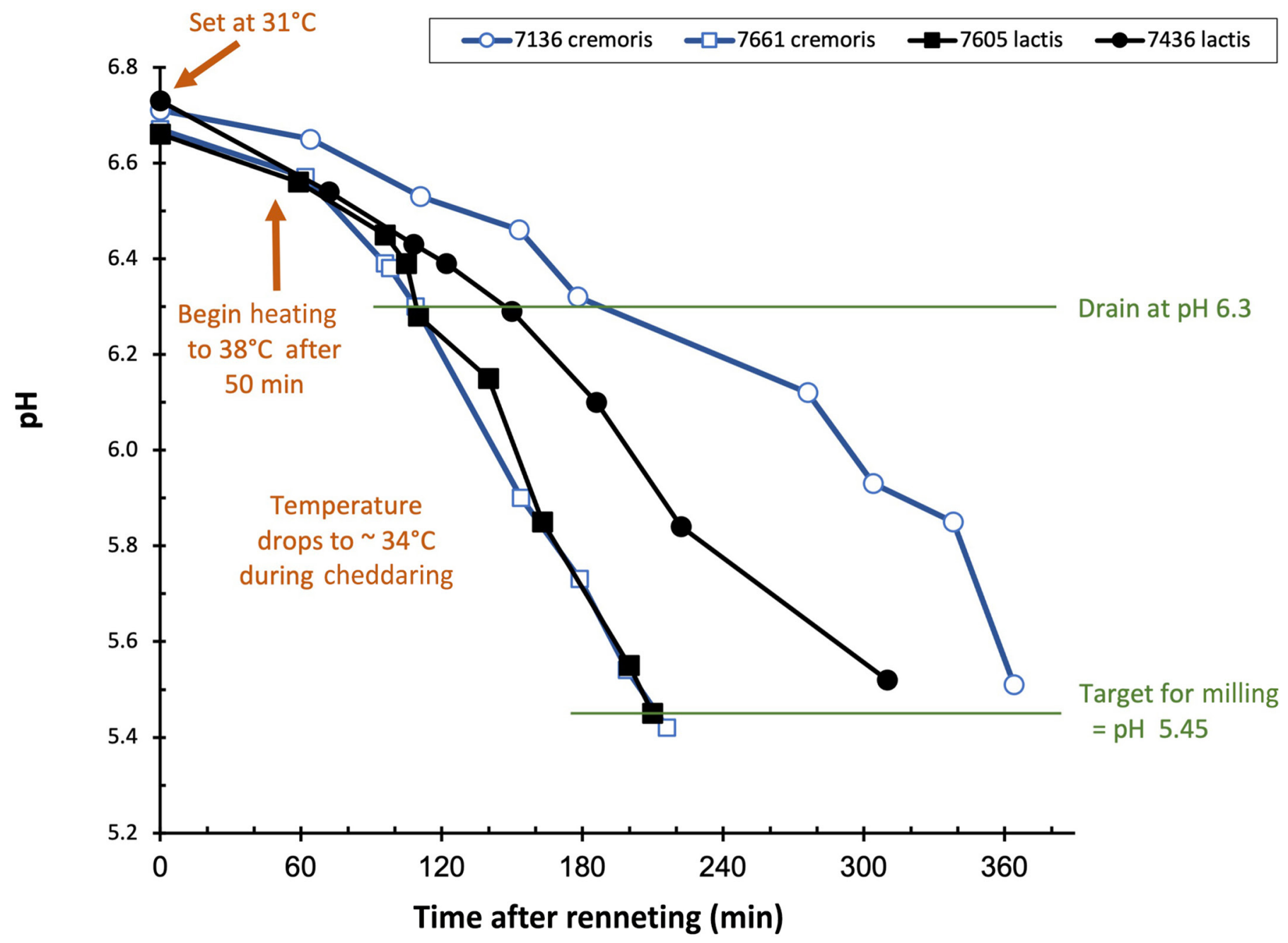

Figure 1. Acidification profile during manufacturing of Cheddar cheese using Lactococcus lactis strains SSM 7605 and SSM 7436 and Lactococcus cremoris strains SSM7136 and SSM 7661 as external pH-controlled bulk starter culture added 5 min before renneting the milk at $31^{\circ} \mathrm{C}$ and then cutting the curd after $30 \mathrm{~min}$. Curd was heated to $38^{\circ} \mathrm{C}$ starting 50 min after cutting, and whey was drained when curd pH 6.3 was reached, then cheddared and milled at a target of $\mathrm{pH} 5.45$.

were not able to determine why this occurred. Another problem is that arginase activity can be a variable trait in L. lactis strains, and Reddy's agar does not always distinguish between the 2 species when cheese is made using a starter culture containing multiple strains.

Another factor affecting enumeration of lactococci is that they form chains of varying length, some of which can be quite long (Figure 3). This needs to be taken into account when comparing total cell numbers of different strains, either by using aseptic high-shear blending to break up the chains before plating (Martley, 1972) or by microscopically determining the average chain length and then multiplying colony-forming units by average chain length to calculate cell numbers. Using a sterile blender to make the first dilution will reduce longer chains to an average of 2.3 to 3 cells per chain
(Lowrie et al., 1972), whereas using a stomacher does not provide enough shear to break up chains. Using microscopy, average chain lengths for the $2 \mathrm{~L}$. lactis strains (SSM 7605 and SSM 7436) were 2.8 and 2.0, respectively. Much longer chains occurred for the $2 \mathrm{~L}$. cremoris strains (SSM 7136 and SSM 7661) with average chain lengths of 16 and 15 , respectively.

To compare cell numbers in the curd during cheesemaking, it is necessary to take into consideration that the starter culture bacteria become concentrated in the curd as whey is expelled from the curd. At the beginning of cheese manufacture, moisture content of the curd at the beginning of cutting is the same as that in the milk before renneting. Since most bacteria are entrapped within the curd particles, when considered on a mass basis, the bacterial cells in the curd undergo an 

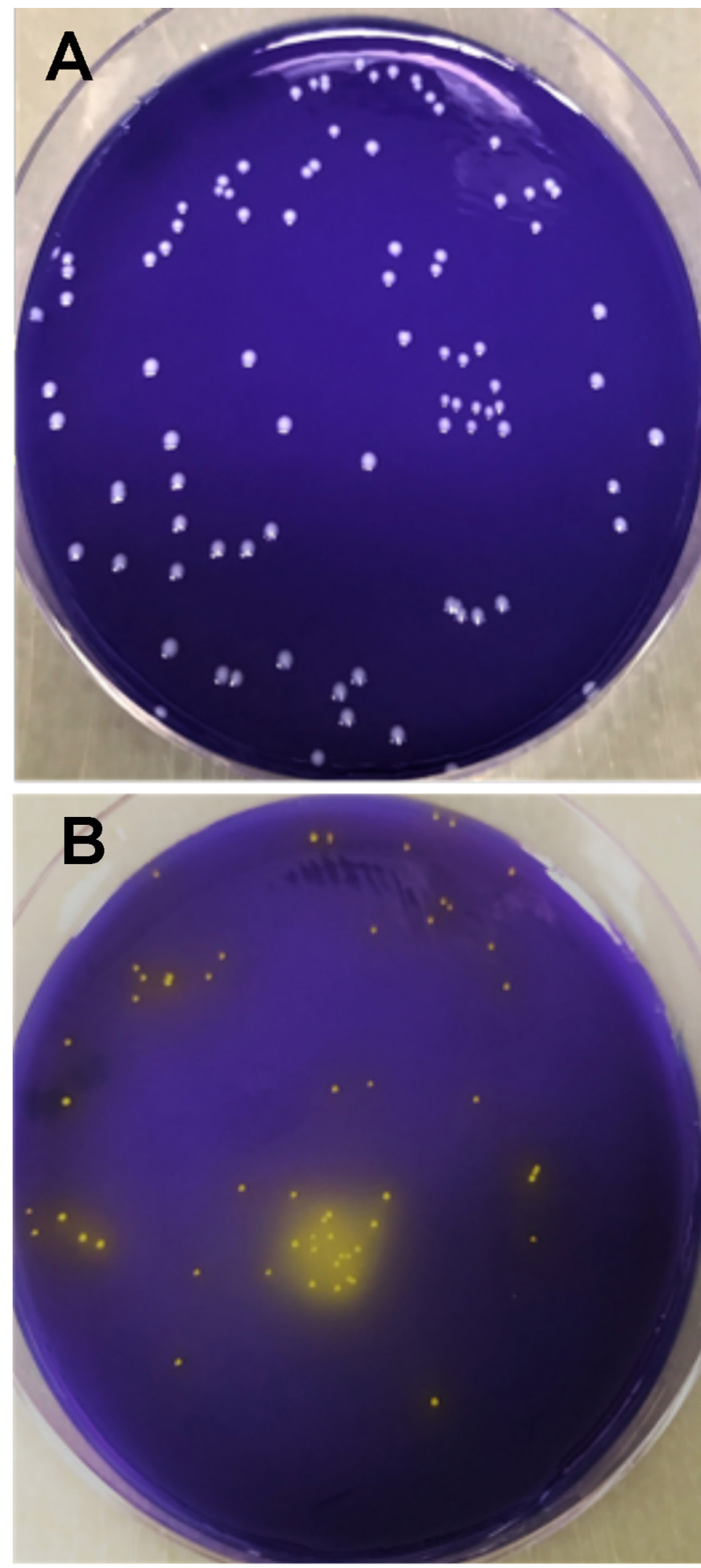

Figure 2. (a) White colonies of Lactococcus lactis and (b) yellow colonies of Lactococcus cremoris grown on Reddy's agar. equivalent concentration as the fat and casein in milk. To compare cell numbers during cheesemaking, this concentration effect needs to be included (Lowrie et al., 1972). Based upon previous manufacture of cheese in the university's creamery it was determined that the solids content of the curd when made from milk containing $12.3 \%$ solids was $14.5 \%$ after the 10 -min cutting process was completed, $31.7 \%$ before draining, $38.3 \%$ after draining, and $56.4 \%$ before milling the curd. To compare all curd bacterial numbers so that they are relative to the final curd before milling, bacterial numbers in the curd in the curd during manufacture were multiplied by concentration factors of $6.4,2.2$, and 1.7, respectively. As whey is expelled from the curd, the protein, fat, and bacterial cells become more concentrated in the curd, and concentration factors were calculated based upon typical curd moisture, fat, and protein contents.

After making this correction for concentration of the bacteria in the curd during cheese manufacture, as well as chain length, the change in cell numbers during cheese manufacture was $<0.5 \log$ (Table 2 ), which is within the generally accepted accuracy of plate counting. Lactococcus cremoris strain SSM 7661 exhibited a slight decline in numbers. By the time of milling, bacterial numbers in the curd were from $2 \times 10^{9}$ to $4 \times$ $10^{9}$ cells/g for all of the strains.

That there was no increase in cell numbers in the curd during cheesemaking is different from what has been observed previously. Lowrie et al. (1972) reported an increase in counts of what were termed bitter lactococcal strains and a decrease in nonbitter lactococcal strains especially after whey draining and during cheddaring. The decrease in numbers varies between strains, with Martley and Lawrence (1972) reporting a $\sim 20 \%$ drop in cell numbers for 2 L. cremoris strains $\left(\mathrm{AM}_{1}\right.$ and $\left.\mathrm{ML}_{1}\right)$ with an $84 \%$ drop in another strain $\left(\mathrm{ML}_{2}\right)$. Martley and Lawrence (1972) had also observed replication of L. cremoris strains that ranged from 0.5 to 3.8 generations until drainage of whey from the curd.

\section{Cheese Composition}

When the amount of salt added to the milled curd was increased, there was a decrease in moisture content in the pressed cheese (Table 3). At the lowest salting level $(2.0 \%)$ cheese moisture after pressing was $36 \%$ and at the highest salting level $(3.6 \%)$ cheese moisture was only $34 \%$ with S/M levels ranging from 3.6 to $5.4 \%$, respectively. This was expected as reducing the salting level is known to decrease the amount of whey expulsion from the cheese during salting and pressing (Sutherland, 1977; Guinee, 2004; McMahon et al., 2014; $\mathrm{Lu}$ and McMahon, 2015). 


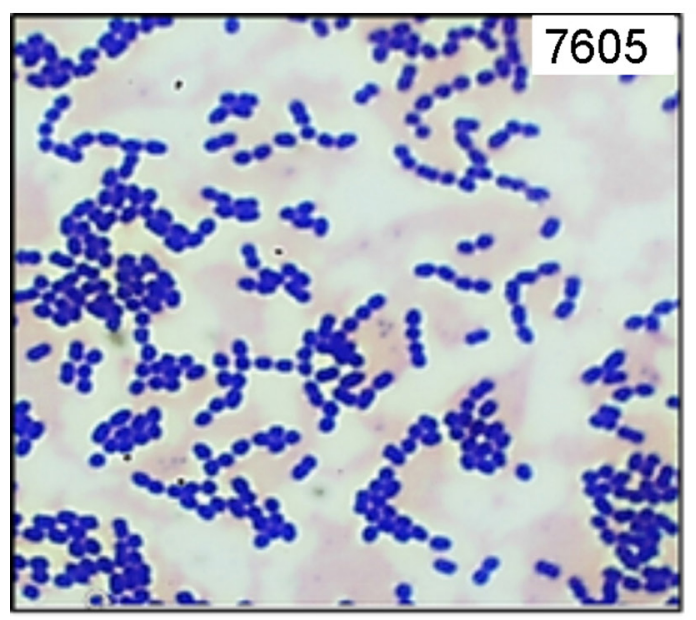

(a)

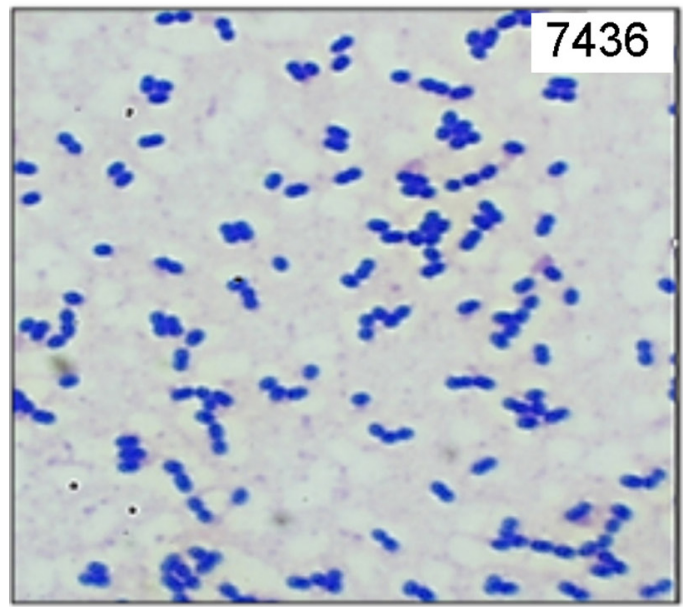

(c)

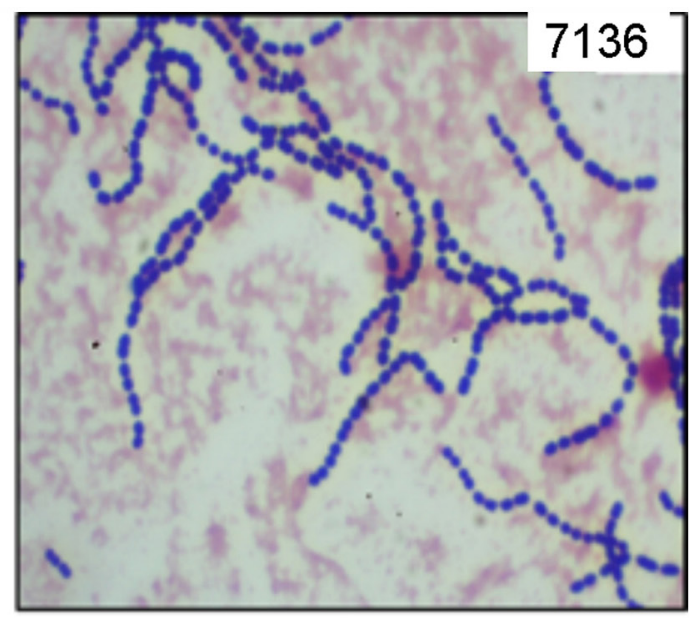

(b)

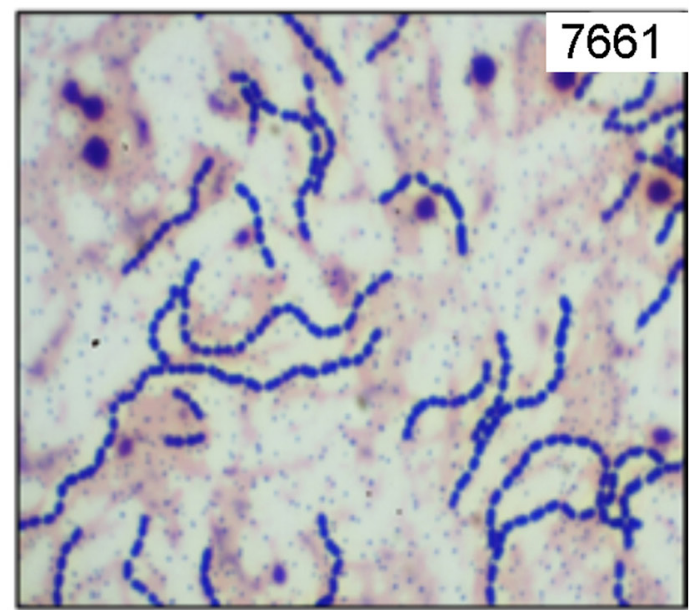

(d)

Figure 3. Gram-stained lactococci showing short chains of Lactococcus lactis strains (a) SSM 7605 and (c) SSM 7436 and long chains of Lactococcus cremoris strains (b) SSM 7136 and (d) SSM 7661.

Fermentation of residual lactose in curd by the starter culture after salting depended on the starter culture strain and the salting level (Table 4). For 2 of the strains, L. lactis SSM 7605 and L. cremoris SSM
7136, the drop in $\mathrm{pH}$ after salting was 0.4 at the lower salting level and only 0.27 at the highest salting level. For L. lactis strain SSM 7436, the $\mathrm{pH}$ drop after salting ranged from about 0.1 to 0.3 units. The difference in

Table 2. Mean ${ }^{1}$ starter culture numbers in cheese curd after accounting for average chain length (2.8, 2.0, 16, and 15 for Lactococcus lactis strains SSM 7605 and SSM 7436 and Lactococcus cremoris strains SSM 7136 and SSM 7661, respectively) and solids concentration in the curd during cheese manufacture $(6.4,2.2$, and 1.7 times for curd after cutting, before draining, and after draining, respectively) relative to the curd before milling, $\mathrm{n}=2$

\begin{tabular}{llcccc}
\hline & & \multicolumn{2}{c}{ Bacterial number } \\
\cline { 3 - 6 } Species & Strain & $\begin{array}{c}\text { After cutting } \\
\text { curd (cells/g) }\end{array}$ & $\begin{array}{c}\text { Before draining } \\
\text { curd (cells/g) }\end{array}$ & $\begin{array}{c}\text { After curd packed } \\
\text { together (cells/g) }\end{array}$ & $\begin{array}{c}\text { Before milling } \\
\text { curd (cells/g) }\end{array}$ \\
\hline L. lactis & SSM 7605 & $1.6 \times 10^{9}$ & $2.0 \times 10^{9}$ & $2.1 \times 10^{9}$ & $2.7 \times 10^{9}$ \\
L. lactis & SSM 7436 & $2.5 \times 10^{9}$ & $1.8 \times 10^{9}$ & $4.3 \times 10^{9}$ & $2.0 \times 10^{9}$ \\
L. cremoris & SSM 7136 & $1.3 \times 10^{9}$ & $1.1 \times 10^{9}$ & $4.3 \times 10^{9}$ & $3.6 \times 10^{9}$ \\
L. cremoris & SSM 7661 & $8.9 \times 10^{9}$ & $5.6 \times 10^{9}$ & $3.6 \times 10^{9}$ \\
\hline
\end{tabular}

${ }^{1} \mathrm{SE}$ ranged from 0.05 to $0.3 \log ($ cells $/ \mathrm{g})$. 
Table 3. Mean moisture, salt, and salt-in-moisture (S/M) of cheese based upon salting level ${ }^{1}$

\begin{tabular}{lccc}
\hline $\begin{array}{l}\text { Salting } \\
\text { level }(\%)\end{array}$ & $\begin{array}{c}\text { Moisture } \\
(\%)\end{array}$ & $\begin{array}{c}\text { Salt } \\
(\%)\end{array}$ & $\begin{array}{c}\mathrm{S} / \mathrm{M}^{2} \\
(\%)\end{array}$ \\
\hline 2.0 & $36.3(0.19)^{3}$ & $1.36(0.03)$ & $3.60(0.09)$ \\
2.4 & $35.9(0.23)$ & $1.43(0.03)$ & $3.86(0.08)$ \\
2.8 & $35.1(0.29)$ & $1.64(0.03)$ & $4.49(0.10)$ \\
3.2 & $34.7(0.23)$ & $1.80(0.06)$ & $4.93(0.16)$ \\
3.6 & $34.0(0.16)$ & $1.95(0.04)$ & $5.40(0.09)$ \\
\hline
\end{tabular}

${ }^{1}$ Salt was added to curd on a wt/wt basis.

${ }^{2} \mathrm{~S} / \mathrm{M}$ measured as salt/(salt + moisture).

${ }^{3}$ Numbers in parentheses are $\mathrm{SE}, \mathrm{n}=8$ (pooled over all 4 strains).

$\mathrm{pH}$ drop after milling can be attributed to differences in moisture content and the salt tolerance of the different starter culture strains. Cheese containing higher moisture, such as those made at the lower salting levels, contains more residual lactose and also has less buffering capacity (i.e., fewer proteins and less phosphate). Such cheeses will experience a larger drop in $\mathrm{pH}$ during and after pressing. The cheese made using $L$. cremoris strain SSM 7661 had virtually no $\mathrm{pH}$ drop after the curd was salted, which suggests this strain was more sensitive to salt than the other 3 strains, although salt tolerance was not determined as part of this study.

\section{Cheese Microbial Counts}

Plate Counts. Based on cheese plate counts after 6 $\mathrm{d}$ of storage and taking into account the average chain length for each strain, ANOVA showed no significant difference in plate counts between $\mathrm{S} / \mathrm{M}$ levels $(P=$ 0.572 ; data not shown). That there was no difference in counts in cheese in which $\mathrm{S} / \mathrm{M}$ was at $5.5 \%$ compared with cheeses with $3.5 \% \mathrm{~S} / \mathrm{M}$ confirms that salt tolerance of modern starter culture strains used in Cheddar cheese manufacture is greater than starter cultures used before the advent of $\mathrm{pH}$-controlled starter cultures in the 1970s as previously reported (McMahon et al., 2014).

The cell counts in cheese significantly differed $(P$ $=0.016$ ) depending on starter culture strain. Because $\mathrm{S} / \mathrm{M}$ was not a significant factor, cell numbers in the cheese were averaged over the 5 salting levels. After taking into account the average chain length, mean lactococcal counts were $2.0 \times 10^{9}, 2.3 \times 10^{9}, 8.7 \times$ $10^{8}$, and $1.3 \times 10^{9}$ for cheese made using strains SSM 7605, SSM 7436, SSM 7136, and SSM 7661, respectively (Table 5). When compared with the cell numbers in the curd before milling (Table 2) and taking into account the $15 \%$ whey expulsion that occurs during salting and pressing, there was little if any decrease in cell numbers during the 6 -d storage for the $2 \mathrm{~L}$. lactis strains, whereas for the $2 \mathrm{~L}$. cremoris strains there was a decrease in bacterial numbers of $\sim 75 \%$.

Flow Cytometry. By using a FL1 threshold of 2,000 , most of the fluorescent counts attributed to noncellular events contributing as background from the diluted citrate extracts of the cheese (as seen in Figure 4) were eliminated. Counts below 2,000 were considered

Table 4. Mean $\mathrm{pH}$ drop in Cheddar cheese after salting, pressing, and 6-d storage at $6^{\circ} \mathrm{C}$ for cheese made using Lactococcus lactis strains SSM 7605 and SSM 7436 and Lactococcus cremoris strains SSM 7136 and SSM 7661 as a function of salting level ${ }^{1}$

\begin{tabular}{|c|c|c|c|c|}
\hline Species & Strain & Milling $\mathrm{pH}$ & $\begin{array}{c}\text { Salting } \\
\text { level (\%) }\end{array}$ & $\mathrm{pH}$ drop \\
\hline \multirow[t]{5}{*}{ L. lactis } & SSM 7605 & $5.40(0.05)^{2}$ & 2.0 & $0.41(0.00)$ \\
\hline & & & 2.4 & $0.36(0.06)$ \\
\hline & & & 2.8 & $0.36(0.01)$ \\
\hline & & & 3.2 & $0.35(0.04)$ \\
\hline & & & 3.6 & $0.27(0.08)$ \\
\hline \multirow[t]{5}{*}{ L. lactis } & SSM 7436 & $5.58(0.09)$ & 2.0 & $0.22(0.09)$ \\
\hline & & & 2.4 & $0.31(0.15)$ \\
\hline & & & 2.8 & $0.13(0.08)$ \\
\hline & & & 3.2 & $0.20(0.07)$ \\
\hline & & & 3.6 & $0.15(0.04)$ \\
\hline \multirow[t]{5}{*}{ L. cremoris } & SSM 7136 & $5.58(0.06)$ & 2.0 & $0.38(0.07)$ \\
\hline & & & 2.4 & $0.35(0.11)$ \\
\hline & & & 2.8 & $0.29(0.08)$ \\
\hline & & & 3.2 & $0.34(0.07)$ \\
\hline & & & 3.6 & $0.27(0.05)$ \\
\hline \multirow[t]{5}{*}{ L. cremoris } & SSM 7661 & $5.44(0.02)$ & 2.0 & $0.09(0.04)$ \\
\hline & & & 2.4 & $0.15(0.04)$ \\
\hline & & & 2.8 & $0.03(0.06)$ \\
\hline & & & 3.2 & $0.03(0.02)$ \\
\hline & & & 3.6 & $-0.02(0.02)$ \\
\hline
\end{tabular}

${ }^{1}$ Salt was added to curd on a wt/wt basis.

${ }^{2}$ Numbers in parentheses are $\mathrm{SE}, \mathrm{n}=2$. 
to occur from extraneous material such as inorganic particles, nonbacterial organic particles, or free DNA binding to the other fluorescent nucleotide dyes (Gatza et al., 2013). A small number of events over 2,000 could still be from noncellular material, as shown in the cytograph of filtered saline (Figure 5). Eliminating such noncellular events is critical when using flow cytometry to study bacterial cells compared with much larger mammalian cells (Bunthof and Abee, 2002). It reduces signal-to-noise ratio and allows a larger proportion of bacterial cells to be included in the total number of events counted by the flow cytometer. It is possible to have less noise (i.e., noncellular material) in the sample by using a hydraulic press to produce a cheese extract from which fat is then physically separating (Sheehan et al., 2005), but this device was not available for our study and such hydraulic pressing takes $4 \mathrm{~h}$ per cheese sample to obtain the extracts.

When bacterial cells are stained using both SG and PI, the population can be divided into 3 groups (Sheehan et al., 2005). We designated these as live-normal cells (live-N) in which fluorescence related to uptake of SG (i.e., FL1) was $\gg$ than fluorescence from PI (i.e., FL3), dead cells in which FL3 was $\gg$ FL1, with an intermediate group considered as live-semipermeable (live-SP) cells for which FL1 was similar to FL3, as shown for similar nucleic acid dyes (Sheehan et al., 2005; Wilkinson, 2018).

For a nucleic acid stain such as SG, both live and dead bacterial cells irrespective of membrane damage fluoresce at $530 \mathrm{~nm}$, whereas fluorescence from PI (>670 nm) occurs with cells that have damaged membranes and are normally be considered dead (Hickey et al., 2015). In addition to live- $\mathrm{N}$ and dead bacterial cells, live-SP cells could be distinguished as shown in UHT milk inoculated with a lactococci starter culture (Figure $6 a)$. Because the culture consisted of multiple L. lactis strains that were incubated overnight and would have reached the stationary phase, it was not unsurprising that the population consisted of live-SP cells and dead cells, as well as live- $\mathrm{N}$ cells. After the fermented milk was heated to kill the starter bacteria, the population consisted only of dead cells (Figure 6b).

The same 3 clusters of bacteria (live-N, live-SP, and dead cells) were observed in flow cytographs of cheese (Figure 7) stained with both SG and PI, although the proportion of live-SP cells was lower than observed in the inoculated milk. Although SG can enter and stain both normal and membrane-damaged cells, the FL1 signal is lowered if PI is present inside the cell because of energy transfer from SG to PI (Sheehan et al., 2005). Correctly setting the discriminator gates to select bacterial counts from background signals is a critical task and could be significant for food samples containing an unknown or variable microbiota (Comas-Riu and Rius, 2009).

When bacterial numbers in the cheese were counted using flow cytometry (Figure 8), statistical significance was observed for the effect of strain on live-N $(P<$ $0.001)$, live-SP $(P=0.038)$, and dead $(P<0.001)$ cells. Salting level was not significant $(P=0.15$ to 0.53$)$, which provides further evidence for lack of salt sensitivity among these starter culture strains. Mean number of cells pooled over salt levels are shown in Table 5 .

Cheese made using L. cremoris strains contained almost 1 log fewer live- $\mathrm{N}$ cells than cheeses made using the $L$. lactis strains $\left(P<0.05\right.$; i.e., $5 \times 10^{8}$ cells $/ g$ compared with $2 \times 10^{9}$ cells $/ \mathrm{g}$, respectively). This is similar to the cell count numbers obtained by plate counting in which there was a half log fewer cells when cheese was made using L. cremoris compared with cheese made using L. lactis strains.

Differences in live-SP cells depended upon the individual strain more than the species designation of lactis or cremoris. Cheeses made using L. lactis SSM 7436 had fewer live-SP cells than cheese made with $L$.

Table 5. Mean number of bacterial cells based upon plate counting on Reddy's agar and multiplying colony-forming units by average chain length for each strain, and cell numbers designated as live-normal (live-N), live-semipermeable (live-SP), and dead bacterial cells as measured by flow cytometry in cheese made using single Lactococcus lactis strains SSM 7605 and SSM 7436 and Lactococcus cremoris strains SSM 7436 and SSM 7661 after $6 \mathrm{~d}$ of storage at $6^{\circ} \mathrm{C}$ and pooled over salt levels

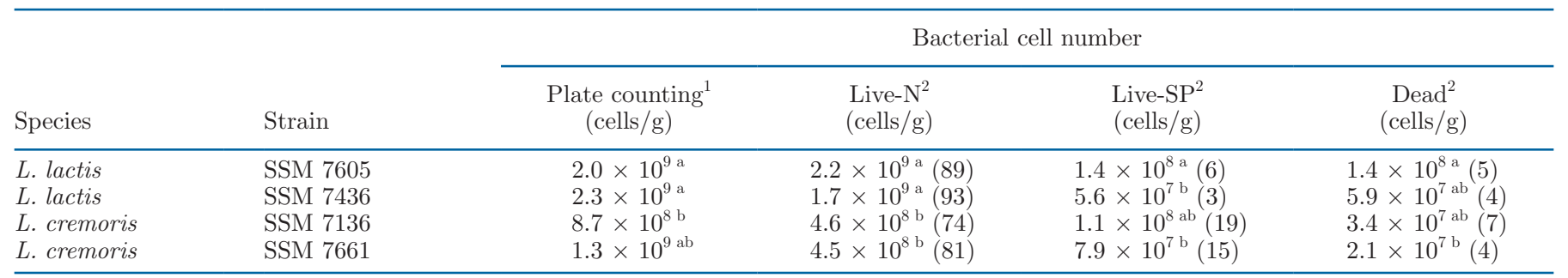

${ }^{\mathrm{a}, \mathrm{b}}$ Means within a column with the same superscript were not significantly different, $\alpha=0.05$.

${ }^{1}$ Cell numbers are cfu/g multiplied by average chain length.

${ }^{2}$ Numbers in parentheses are the percentage of the total population for each strain that were live-N, live-SP, and dead cells. 
lactis $\operatorname{SSM} 7605\left(P<0.05\right.$; i.e., $1.4 \times 10^{8}$ and $5.6 \times$ $10^{7}$, respectively; Table 5). Similar cell numbers were obtained L. cremoris strains with levels of $1.1 \times 10^{8}$ and $7.9 \times 10^{7}$ for cheeses made using $L$. cremoris $\mathrm{SSM}$ 7136 and L. cremoris SSM 7661, respectively, although these were not significantly different from each other
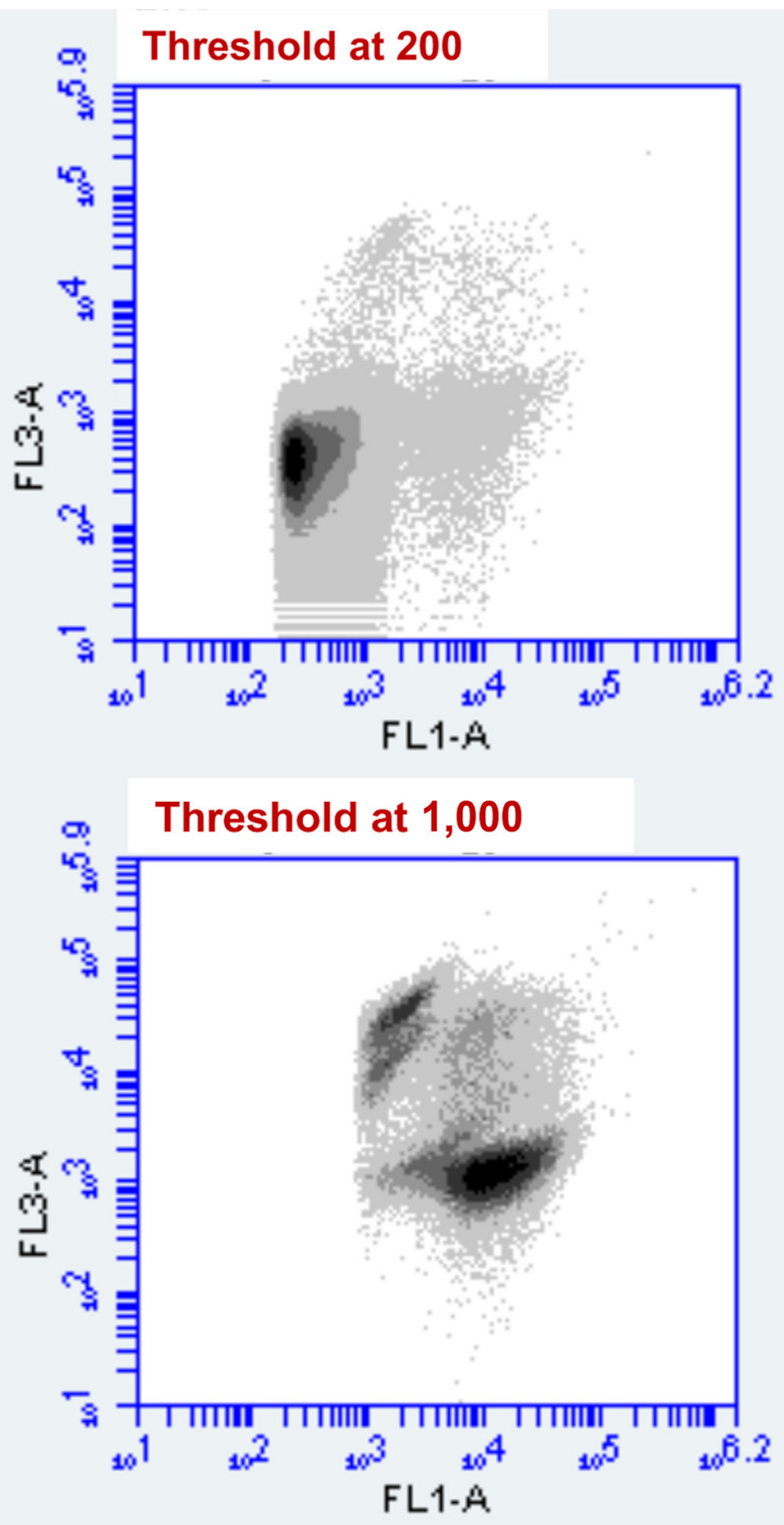

Figure 4. Flow cytographs of a cheese preparation stained with SYBR Green (FL1-A; Invitrogen) and propidium iodide (FL3-A; Sigma-Aldrich) showing the effect of threshold level on proportion of total events recorded that were cellularly related when the FL1-A threshold was set at 200 or 1,000 .

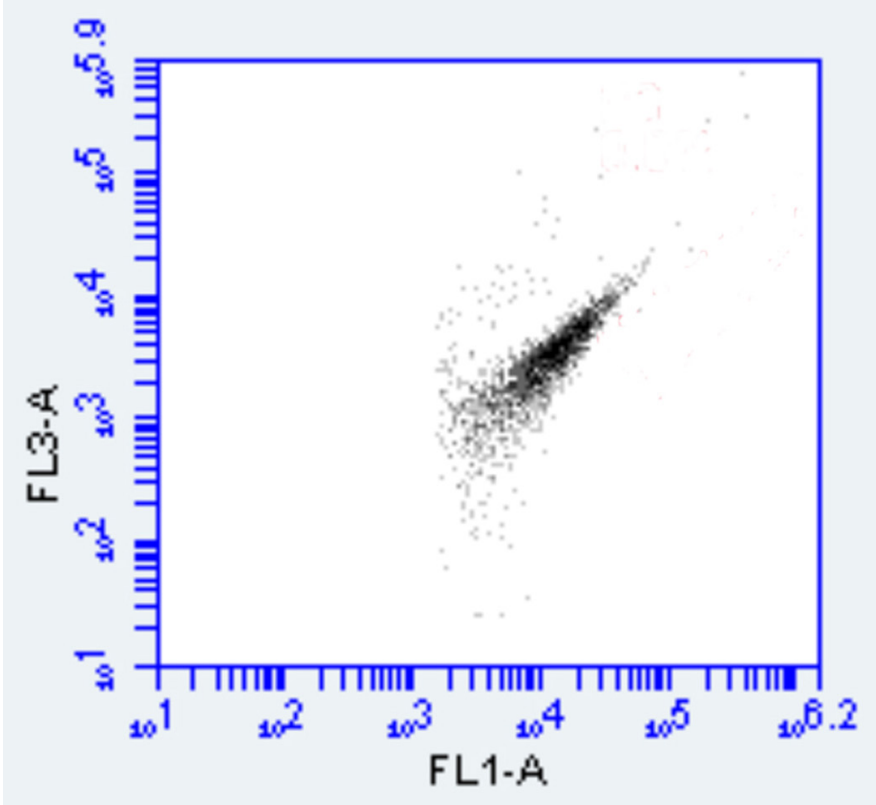

Figure 5. Flow cytograph of 0.2-mm filtered saline showing fluorescence from SYBR Green (FL1-A; Invitrogen) and propidium iodide (FL3-A; Sigma-Aldrich) and the presence of some noncellular events above the FL1-A threshold of 2,000.

(Table 5). However, when considered on a percentage basis of the total cell population, the cheeses made using L. lactis had 3 to $6 \%$ of cells classified as live-SP. For the cheese made using $L$. cremoris, the proportion of cells that were classified as live-SP was 15 to $19 \%$.

As a percentage of the total cell population, all of the cheeses contained similar proportions of dead cells (i.e., 4 to 7\%; Table 5). The cheese made using $L$. cremoris contained a higher proportion of live-SP cells than the $L$. lactis strains, and hence they contained a lower proportion of live-N cells. When comparing cell numbers obtained by plate counting with the live-N numbers, cell numbers were the same for cheese made using $L$. lactis but live- $\mathrm{N}$ numbers were lower than plate count numbers for cheese made using L. cremoris (Table 5). This could be due to some of the cells classified as live-SP still being culturable or just misclassified in the cytographs. It has been suggested that when starter culture cells become semipermeable this may cause them to be nonculturable even though they are still metabolically active (Ganesan et al., 2007; Ruggirello et al., 2014, 2016). Another explanation may be that the stomaching of the cheese samples caused some breakage of the longer L. cremoris chains of cells so that the average cell length was shorter than the 16 and 15 originally calculated. While stomaching would not provide sufficient shear to reduce the average chain 


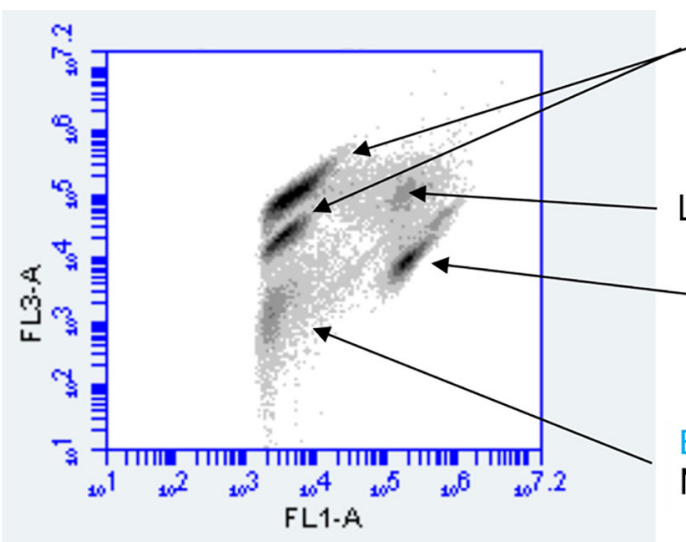

(a) Cultured milk

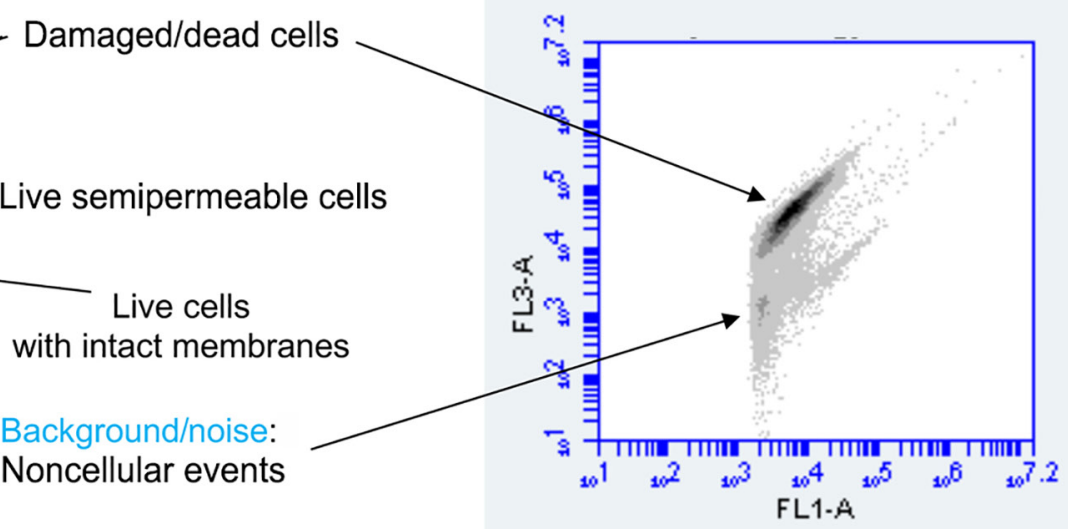

(b) Cultured milk after heating

Figure 6. Flow cytographs of (a) milk cultured with lactococcal starter and (b) after heating at $85^{\circ} \mathrm{C}$ for 12 min showing fluorescence from SYBR Green (FL1-A; Invitrogen) and propidium iodide (FL3-A; Sigma-Aldrich).

length to 2 to 3 as does blending (Lowrie et al., 1972), if the average chain length was reduced by half then the plate count cell numbers would be the same as the live-N numbers.

A precise separation of live- $\mathrm{N}$ from live-SP cells is difficult as the extent of permeability as shown by relative fluorescence from PI and SG occurs over a continuum rather than as discrete categories. Nevertheless, it demonstrates the usefulness and perhaps the necessity of considering bacterial cells that may be unculturable but still metabolically active (as well as those that are culturable or have lysed and released intracellular enzymes into the cheese serum) when considering biochemical events that are important in cheese flavor development during cheese storage.

\section{CONCLUSIONS}

Rate of acid production by a lactococcal starter culture during Cheddar cheese manufacture is dependent on the strain's tolerance to cook temperature and not classification as L. lactis or L. cremoris. There was no increase in cell numbers from time of cutting to milling of curd when concentration effect of whey expulsion was considered. Increasing salt addition from 3.5 to $5.5 \% \mathrm{~S} / \mathrm{M}$ did not affect post-salting fermentation, and only one strain was inhibited by salting. Bacterial cell numbers in the cheese after $6 \mathrm{~d}$ of storage obtained by plate counting were similar to cell numbers considered as live- $\mathrm{N}$ when measured using flow cytometry. Based on flow cytometry measurements, 3 to $6 \%$ of

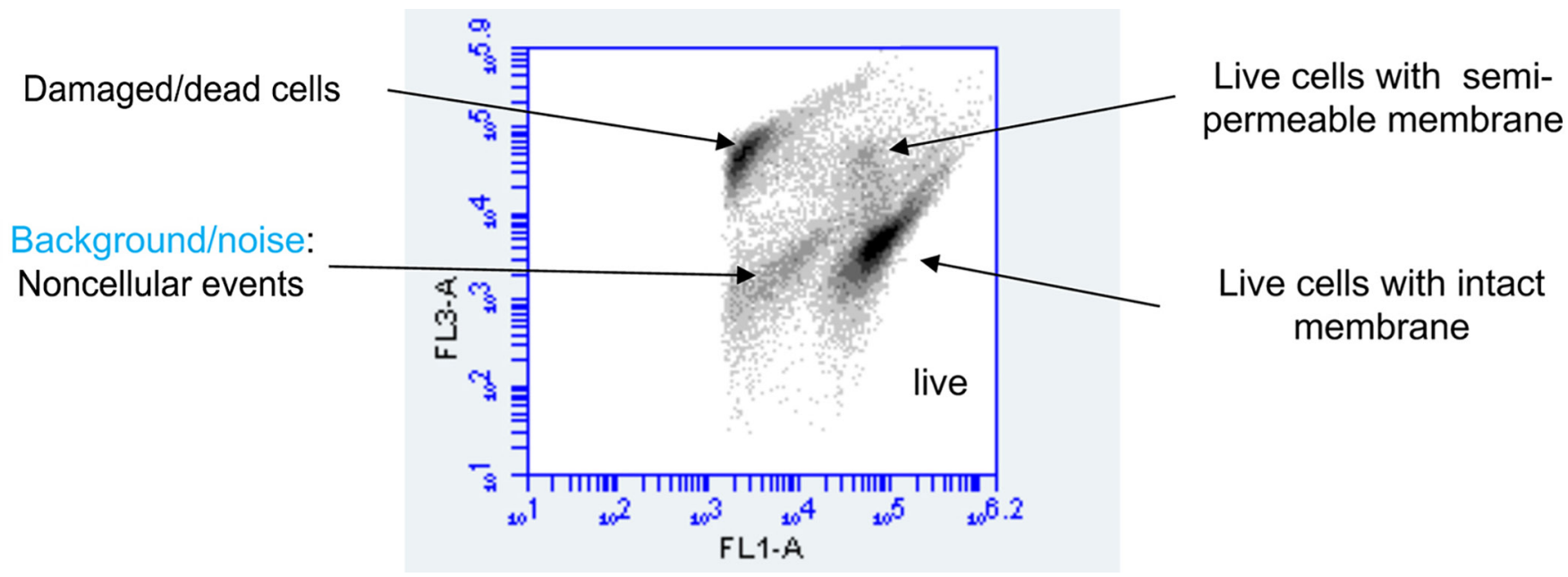

Figure 7. Flow cytograph of a diluted cheese slurry showing fluorescence from SYBR Green (FL1-A; Invitrogen) and propidium iodide (FL3-A; Sigma-Aldrich). 
the total starter culture cells in the cheese after $6 \mathrm{~d}$ of storage were classified as dead. For cheese made using L. cremoris strains, 13 to $16 \%$ of cells were classified as semipermeable compared with only 3 to $6 \%$ of the cells in cheese made using L. lactis strains. Further research is needed to determine if cells considered live-SP are culturable on plate count media, whether they increase in number during cheese storage, and whether they are metabolically active and play a role in Cheddar cheese flavor development.

\section{ACKNOWLEDGMENTS}

R. Poudel was supported by funding from the Building University-Industry Linkages through learn- ing and Discovery (BUILD) Dairy program of the Western Dairy Center (Utah State University, Logan) with financial support from Dairy West (Meridian, ID) and regional dairy processing companies. The authors thank the Aggie Creamery (Logan, UT) staff for providing the pasteurized milk and assistance in cheesemaking, and Deana Larsen (Utah State University) for training R. Poudel in flow cytometry. This research was also supported by the Utah Agricultural Experiment Station, Utah State University, and approved as journal paper number 9401. R. K. Thunell is employed by Vivolac Cultures Corporation (Greenfield, IN) who provided the strains of starter culture used in this study. The authors have not stated any conflicts of interest.

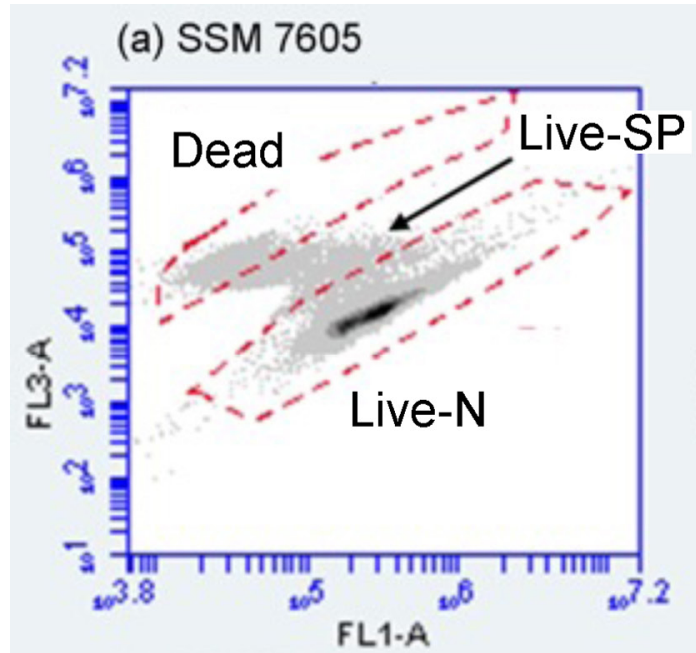

\section{(b) SSM 7434}

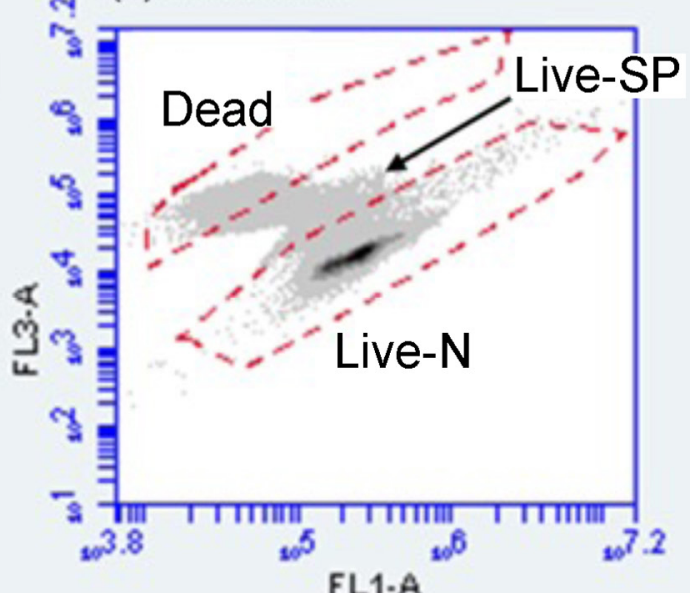

(c) SSM 7136
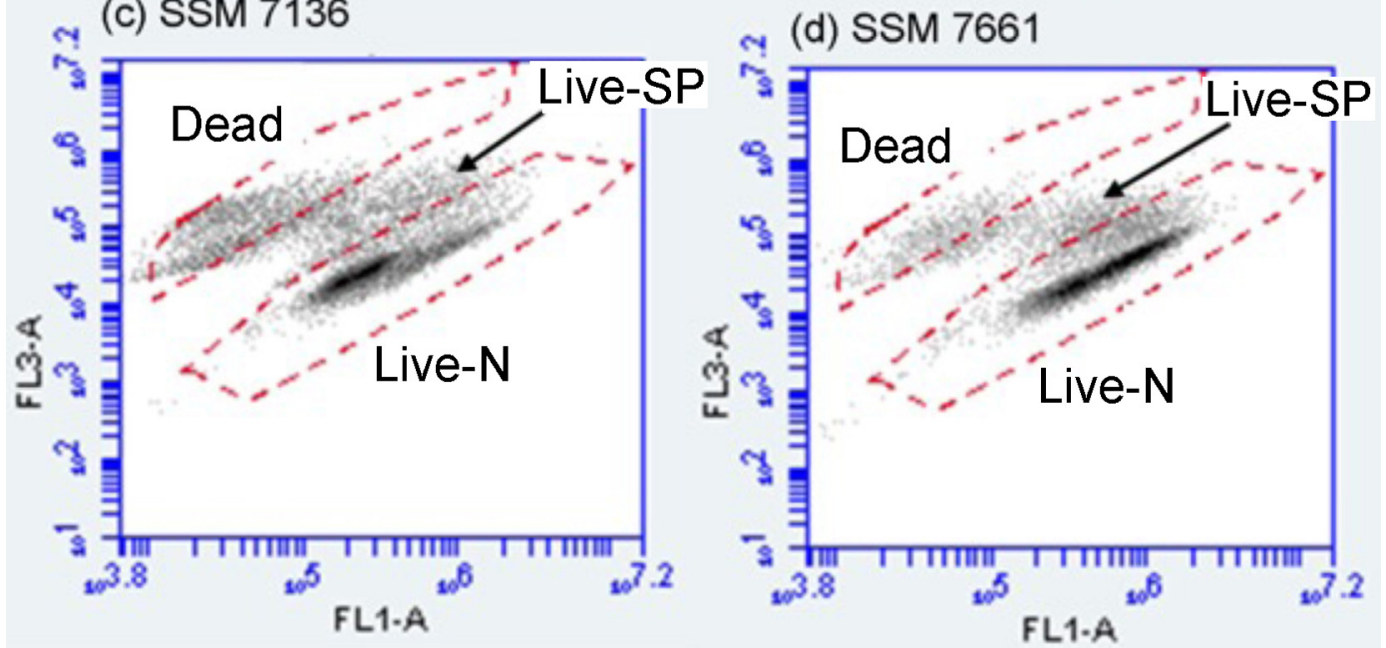

Figure 8. Flow cytographs of diluted cheese slurry. Flow cytographs showing fluorescence from SYBR Green (FL1-A; Invitrogen) and propidium iodide (FL3-A; Sigma-Aldrich) for bacteria extracted from cheeses made using Lactococcus lactis strains (a) SSM 7605 and (b) SSM 7434 and Lactococcus cremoris strains (c) SSM 7136 and (d) SSM 7661 with events previously considered noncellular gated out, and showing gated events for live and dead cells with the remaining events classified as live-semipermeable cells. Live-N $=$ live-normal; live-SP $=$ live-semipermeable. 


\section{REFERENCES}

Breheny, S., M. Kanasaki, A. J. Hillier, and G. R. Jago. 1975. Effect of temperature on the growth and acid production of lactic acid bacteria. Australian J. Dairy Technol. 30:145-148.

Bunthof, C. J., and T. Abee. 2002. Development of a flow cytometric method to analyze subpopulations of bacteria in probiotic products and dairy starters. Appl. Environ. Microbiol. 68:2934-2942. https://doi.org/10.1128/AEM.68.6.2934-2942.2002.

Chen, J., J. Shen, L. I. Hellgren, P. R. Jensen, and C. Solem. 2015. Adaptation of Lactococcus lactis to high growth temperature leads to a dramatic increase in acidification rate. Sci. Rep. 5:14199. https: //doi.org/10.1038/srep14199.

Comas-Riu, J., and N. Rius. 2009. Flow cytometry applications in the food industry. J. Ind. Microbiol. Biotechnol. 36:999-1011. https:/ doi.org/10.1007/s10295-009-0608-x.

Crow, V. L., T. Coolbear, R. Holland, G. G. Pritchard, and F. G. Martley. 1993. Starters as finishers: Starter properties relevant to cheese ripening. Int. Dairy J. 3:423-460. https://doi.org/10.1016/ 0958-6946(93)90026-V.

Fernández, E., Á. Alegría, S. Delgado, M. C. Martín, and B. Mayo. 2011. Comparative phenotypic and molecular genetic profiling of wild Lactococcus lactis ssp. lactis strains of the L. lactis subsp. lactis and L. lactis subsp. cremoris genotypes, isolated from starterfree cheeses made of raw milk. Appl. Environ. Microbiol. 77:53245335. https://doi.org/10.1128/AEM.02991-10.

Ganesan, B., M. R. Stuart, and B. C. Weimer. 2007. Carbohydrate starvation causes a metabolically active but nonculturable state in Lactococcus lactis. Appl. Environ. Microbiol. 73:2498-2512. https: //doi.org/10.1128/AEM.01832-06.

Gatza, E., F. Hammes, and E. Prest. 2013. Assessing Water Quality with the BD Accuri ${ }^{\mathrm{TM}}$ C6 Flow Cytometer. Accessed Dec. 20, 2021. https://www.bdbiosciences.com/content/dam/bdb/marketing -documents/Accuri-WP-Assessing-Water-Quality.pdf.

Guinee, T. P. 2004. Salting and the role of salt in cheese. Int. J. Dairy Technol. 57:99-109. https://doi.org/10.1111/j.1471-0307 .2004.00145.x.

Hickey, C. D., M. A. E. Auty, M. G. Wilkinson, and J. J. Sheehan. 2015. The influence of cheese manufacture parameters on cheese microstructure, microbial localisations and their interactions during ripening: A review. Trends Food Sci. Technol. 41:135-148. https://doi.org/10.1016/j.tifs.2014.10.006.

Hillier, A. J., M. Kanasaki, and G. R. Jago. 1975. The effect of temperature on the growth and acid production of lactic acid bacteria. Australian J. Dairy Technol. 30:149-152.

Kim, W. S., J. Ren, and N. W. Dunn. 1999. Differentiation of Lactococcus lactis subspecies lactis and subspecies cremoris strains by their adaptive response to stresses. FEMS Microbiol. Lett. 171:5765. https://doi.org/10.1111/j.1574-6968.1999.tb13412.x.

Lee, D. A., and E. B. Collins. 1976. Influence of temperature on growth of Streptococcus cremoris and Streptococcus lactis. J. Dairy Sci. 59:405-409. https://doi.org/10.3168/jds.S0022-0302(76)84220-8.

Li, T. T., W. L. Tian, and C. T. Gu. 2019. Elevation of Lactococcus lactis subsp. cremoris to the species level as Lactococcus cremoris sp. nov. and transfer of Lactococcus lactis subsp. tructae to Lactococcus cremoris as Lactococcus cremoris subsp. tructae comb. nov. Int. J. Syst. Evol. Microbiol. 71:004727. https://doi.org/10.1099/ ijsem.0.004727.

Limsowtin, G. K. Y., H. A. Heap, and R. C. Lawrence. 1977. A multiple starter concept for cheese making. N. Z. J. Dairy Sci. Technol. 12:101-106.

Lowrie, R. J., and R. C. Lawrence. 1972. Cheddar cheese flavour. IV. A new hypothesis to account for the development of bitterness. N. Z. J. Dairy Sci. Technol. 7:51-53.
Lowrie, R. J., R. C. Lawrence, L. E. Pearce, and E. L. Richards. 1972. Cheddar cheese flavour. III. The growth of lactic streptococci during cheese making and its effect on bitterness development. N. Z. J. Dairy Sci. Technol. 7:44-50.

Lu, Y., and D. J. McMahon. 2015. Effects of sodium chloride salting and substitution with potassium chloride on whey expulsion of Cheddar cheese. J. Dairy Sci. 98:78-88. https://doi.org/10.3168/ jds.2014-8600.

Martley, F. G. 1972. The effect of cell numbers in streptococcal chains on plate-counting. N. Z. J. Dairy Sci. Technol. 7:7-11.

Martley, F. G., and R. C. Lawrence. 1972. Cheddar cheese flavor. II. Characteristics of single strain starters associated with good or poor flavour development. N. Z. J. Dairy Sci. Technol. 7:38-44.

McMahon, D. J., C. J. Oberg, M. A. Drake, N. Farkye, L. V. Moyes, M. R. Arnold, B. Ganesan, J. Steele, and J. R. Broadbent. 2014. Effect of sodium, potassium, magnesium, and calcium salt cations on $\mathrm{pH}$, proteolysis, organic acids, and microbial populations during storage of full-fat Cheddar cheese. J. Dairy Sci. 97:4780-4798. https://doi.org/10.3168/jds.2014-8071.

Reddy, M. S., E. R. Vedamuthu, C. J. Washam, and G. W. Reinbold. 1972. Agar medium for differential enumeration of lactic streptococci. Appl. Microbiol. 24:947-952. https://doi.org/10.1128/am.24 .6.947-952.1972.

Richardson, G. H., C. T. Cheng, and R. Young. 1977. Lactic bulk culture system utilizing whey-based bacteriophage inhibitory medium and $\mathrm{pH}$ control. 1. Applicability to American style cheese. J. Dairy Sci. 60:378-386. https://doi.org/10.3168/jds.S0022-0302(77)83876 -9 .

Ruggirello, M., L. Cocolin, and P. Dolci. 2016. Fate of Lactococcus lactis starter cultures during late ripening in cheese models. Food Microbiol. 59:112-118. https://doi.org/10.1016/j.fm.2016.05.001.

Ruggirello, M., P. Dolci, and L. Cocolin. 2014. Detection and viability of Lactococcus lactis throughout cheese ripening. PLoS One 9:e114280. https://doi.org/10.1371/journal.pone.0114280.

Sheehan, A., C. O'Loughlin, G. O'Cuinn, R. J. FitzGerald, and M. G. Wilkinson. 2005. Cheddar cheese cooking temperature induces differential lactococcal cell permeabilization and autolytic responses as detected by flow cytometry: implications for intracellular enzyme accessibility. J. Appl. Microbiol. 99:1007-1018. https://doi .org/10.1111/j.1365-2672.2005.02718.x.

Sutherland, B. J. 1977. Some observations on salt and moisture concentration gradients in Cheddar cheese. Australian J. Dairy Sci. Technol. $\quad 32: 17-18 \quad$ http://hdl.handle.net/102.100.100/302546 ?index $=1$.

Turner, K. W., and T. D. Thomas. 1975. Uncoupling of growth and acid production in lactic streptococci. N. Z. Dairy Sci. Technol. 10:162-167.

Wilkinson, M. G. 2018. Flow cytometry as a potential method of measuring bacterial viability in probiotic products: A review. Trends Food Sci. Technol. 78:1-10. https://doi.org/10.1016/j.tifs.2018.05 .006 .

\section{ORCIDS}

Randall K. Thunell @ https://orcid.org/0000-0003-0192-2237 Craig J. Oberg @ https://orcid.org/0000-0001-6033-7033 Taylor S. Oberg @ https://orcid.org/0000-0003-1890-5927 Donald. J. McMahon (ํ) https://orcid.org/0000-0002-7923-8542 